\title{
Chaotic Extension Neural Network-Based Fault Diagnosis Method for Solar Photovoltaic Systems
}

\author{
Kuo-Nan Yu, Her-Terng Yau, and Jian-Yu Li \\ Department of Electrical Engineering, National Chin-Yi University of Technology, No. 57, Section 2, Zhongshan Road, \\ Taiping District, Taichung 41170, Taiwan \\ Correspondence should be addressed to Her-Terng Yau; pan1012@ms52.hinet.net
}

Received 9 April 2014; Accepted 20 April 2014; Published 13 May 2014

Academic Editor: Yunhua Li

Copyright (C) 2014 Kuo-Nan Yu et al. This is an open access article distributed under the Creative Commons Attribution License, which permits unrestricted use, distribution, and reproduction in any medium, provided the original work is properly cited.

At present, the solar photovoltaic system is extensively used. However, once a fault occurs, it is inspected manually, which is not economical. In order to remedy the defect of unavailable fault diagnosis at any irradiance and temperature in the literature with chaos synchronization based intelligent fault diagnosis for photovoltaic systems proposed by Hsieh et al., this study proposed a chaotic extension fault diagnosis method combined with error back propagation neural network to overcome this problem. It used the nn toolbox of matlab 2010 for simulation and comparison, measured current irradiance and temperature, and used the maximum power point tracking (MPPT) for chaotic extraction of eigenvalue. The range of extension field was determined by neural network. Finally, the voltage eigenvalue obtained from current temperature and irradiance was used for the fault diagnosis. Comparing the diagnostic rates with the results by Hsieh et al., this scheme can obtain better diagnostic rates when the irradiances or the temperatures are changed.

\section{Introduction}

This study focused on solar photovoltaic fault diagnosis. Solar energy is generated from the sunlight, which is an inexhaustible renewable energy, as compared to other green energies. At present, the solar photovoltaic system has been used in many fields, and current research focuses are the use of this technology, such as efficient storage, environmental issues, and subsequent maintenance. The analysis based on fault diagnosis technology can save labor cost greatly.

Many studies have proposed fault diagnosis technologies for photovoltaic system. Most of traditional fault diagnosis technologies are based on intelligent algorithms including neural network [1-3]. For example, in 2009, Wu et al. used BP neural network for fault diagnosis, the diagnostic rate was very high, but a large amount of data was required for learning and training. The convergence of samples was time consuming [4]. In 2011, Syafaruddin et al. used threelayer artificial neural network for fault diagnosis and provided more accurate diagnostic result than one-layer fault diagnosis. However, this method was also time consuming [5]. In 2011, Shimakage et al. discussed photovoltaic system fault diagnosis and used measurement and observation for diagnosis. They recorded the power generated by the faulted photovoltaic system and compared it with the presently measured power. However, the data for comparison were required and time was required to create the database [6]. In 2012, Zhao et al. proposed a decision tree-based diagnostic method for photovoltaic cell. The diagnostic rate of this method was as high as $99.8 \%$, but more than 1,000 times of intercomparison were required in the course of diagnosis [7]. In 2014, Tadj et al. proposed a GISTEL (gisement solaire par télédetection: solar radiation by teledetection) model to improve the photovoltaic cell diagnosis on fuzzy logic estimated satellite image. The method was difficult to be implemented [8]. In 2014, Hsieh et al. used chaotic extension theory for diagnosis, and the accuracy rate was very high. However, due to the limitation of extension theory, the diagnostic rate decreased greatly when the temperature and irradiance changed. This study aims to remedy the defects in the literature [9].

In the literature [9], 10-series 2-parallel solar photovoltaic array was used as the model of fault diagnosis. Chaotic synchronization system was combined with extenics for fault diagnosis. However, the classical domain cannot identify 


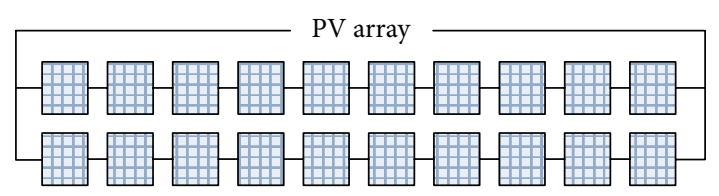

FIGURE 1: 10-series 2-parallel schematic diagram.

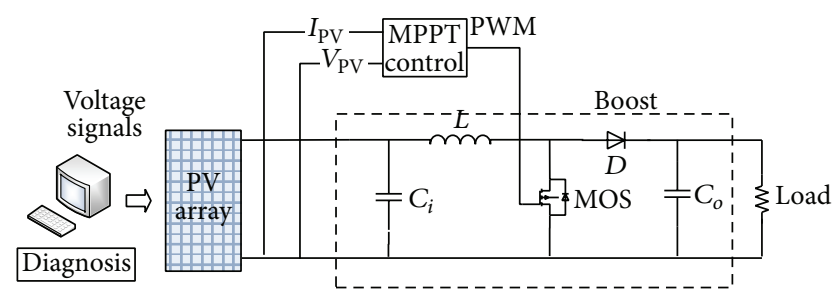

Figure 2: MPPT control system schematic diagram.

TABLE 1: Solar panel model and specifications.

\begin{tabular}{lc}
\hline Solar panel model & SM 1611 \\
Maximum power $\left(P_{\mathrm{MAX}}\right)$ & $1.65 \mathrm{~W}$ \\
Open-circuit voltage $\left(V_{\mathrm{OC}}\right)$ & $3.0 \mathrm{~V}$ \\
Short-circuit current $\left(I_{\mathrm{SC}}\right)$ & $0.8 \mathrm{~A}$ \\
\hline
\end{tabular}

the fault state accurately as long as the irradiance and temperature have changed. This study uses BP neural network, so as to remedy the defect of unavailable diagnosis when the irradiance and temperature change, and uses the center of error dynamic trajectories of two chaotic subsystems as eigenvalue, to overcome the decrease in diagnostic rate that resulted from undervoltage at low light level.

\section{Architecture of Solar Power System}

The fault diagnosis module used in this paper is 10-series 2parallel photovoltaic, as shown in Figure 1, and MPPT, the system architecture, is shown in Figure 2; the matlab 2010 is used for simulation. The specifications of SM1611 photovoltaic cell are shown in Table 1 [9].

The photovoltaic cell is set as short circuit to simulate nine fault states to be illustrated by Table 2, and the I-V and $\mathrm{P}-\mathrm{V}$ characteristic curves at different irradiances and temperatures are observed.

\section{Research Method}

3.1. Chaos Synchronization Theory. The chaos synchronization theory designs a slave system to synchronize a master system. The chaos synchronization system consists of two subsystems, a master system and a slave system, representing the relation between master and servant. This paper uses Lorenz chaos synchronization system, which is highly sensitive to parametric variation, to capture the voltage signal of photovoltaic system and extract the kinematic trajectory of dynamic error. The center of this kinematic trajectory is used
TABLE 2: Solar photovoltaic system fault category.

\begin{tabular}{|c|c|}
\hline $\begin{array}{l}\text { Fault } \\
\text { category }\end{array}$ & Fault condition (short circuit set in faulted solar cell) \\
\hline $\begin{array}{l}\text { Case } 1 \\
(\mathrm{C} 1)\end{array}$ & $\begin{array}{l}\text { There is no fault in two-series connected } \\
\text { photovoltaic cells. }\end{array}$ \\
\hline $\begin{array}{l}\text { Case } 2 \\
(\mathrm{C} 2)\end{array}$ & $\begin{array}{l}\text { One solar cell fault occurs in any series branch of } \\
\text { two-series branch photovoltaic system. }\end{array}$ \\
\hline $\begin{array}{l}\text { Case } 3 \\
(\mathrm{C} 3)\end{array}$ & $\begin{array}{l}\text { Two solar cells have faults in any series branch of } \\
\text { two-series branch photovoltaic system. }\end{array}$ \\
\hline $\begin{array}{l}\text { Case } 4 \\
(\mathrm{C} 4)\end{array}$ & $\begin{array}{l}\text { Three solar cells have faults in any series branch of } \\
\text { two-series branch photovoltaic system. }\end{array}$ \\
\hline $\begin{array}{l}\text { Case } 5 \\
(\mathrm{C} 5)\end{array}$ & $\begin{array}{l}\text { One solar cell fault occurs in both of the two-series } \\
\text { branches of two-series branch photovoltaic system. }\end{array}$ \\
\hline $\begin{array}{l}\text { Case } 6 \\
\text { (C6) }\end{array}$ & $\begin{array}{l}\text { Two solar cells have faults in both of the two-series } \\
\text { branches of two-series branch photovoltaic system. }\end{array}$ \\
\hline $\begin{array}{l}\text { Case } 7 \\
\text { (C7) }\end{array}$ & $\begin{array}{l}\text { In the two-series branch photovoltaic system, one } \\
\text { solar cell has fault in one-series branch and two solar } \\
\text { cells have faults in the other branch. }\end{array}$ \\
\hline $\begin{array}{l}\text { Case } 8 \\
(\mathrm{C} 8)\end{array}$ & $\begin{array}{l}\text { In the two-series branch photovoltaic system, one } \\
\text { solar cell has fault in one-series branch and four } \\
\text { solar cells have faults in the other branch. }\end{array}$ \\
\hline $\begin{array}{l}\text { Case } 9 \\
(\mathrm{C} 9)\end{array}$ & $\begin{array}{l}\text { In the two-series branch photovoltaic system, two } \\
\text { solar cells have faults in one-series branch and three } \\
\text { solar cells have faults in the other branch. }\end{array}$ \\
\hline
\end{tabular}

as the eigenvalue of fault. The architecture of Lorenz chaos synchronization system is expressed as follows [10]:

$$
\begin{aligned}
& \text { Master: }\left\{\begin{array}{l}
\dot{x}_{1}=\alpha\left(x_{2}-x_{1}\right) \\
\dot{x}_{2}=\beta x_{1}-x_{1} x_{3}-x_{2} \\
\dot{x}_{3}=x_{1} x_{2}-\gamma x_{3},
\end{array}\right. \\
& \text { Slave: }\left\{\begin{array}{l}
\dot{y}_{1}=\alpha\left(y_{2}-y_{1}\right) \\
\dot{y}_{2}=\beta y_{1}-y_{1} y_{3}-y_{2} \\
\dot{y}_{3}=y_{1} y_{2}-\gamma y_{3},
\end{array}\right.
\end{aligned}
$$

where $\alpha, \beta$, and $\gamma$ are system parameters and $x$ and $y$ are the state variables. The master-slave system error state can be expressed as $e_{1}=x_{1}-y_{1}, e_{2}=x_{2}-y_{2}$, and $e_{3}=x_{3}-y_{3}$; the dynamic error system is expressed as follows [10]:

$$
\left[\begin{array}{c}
\dot{e}_{1} \\
\dot{e}_{2} \\
\dot{e}_{3}
\end{array}\right]=\left[\begin{array}{ccc}
-\alpha & \alpha & 0 \\
\beta & -1 & 0 \\
0 & 0 & -\gamma
\end{array}\right]\left[\begin{array}{l}
e_{1} \\
e_{2} \\
e_{3}
\end{array}\right]+\left[\begin{array}{c}
0 \\
-x_{1} x_{3}+y_{1} y_{3} \\
x_{1} x_{2}-y_{1} y_{2}
\end{array}\right] .
$$

This paper uses the final dynamic errors $\dot{e}_{1}, \dot{e}_{2}$, and $\dot{e}_{3}$ to draw the dynamic error trajectory diagram for observation.

3.2. Extension Theory. The extension theory solves contradiction problem quantitatively and qualitatively to change it into compatibility problem. The difference between extension theory and fuzzy theory is that the range of fuzzy set is $\langle 0,1\rangle$, whereas the extension is a real number extended from $\langle 0,1\rangle$ to $\langle-\infty, \infty\rangle[11]$. The extension theory is characterized by a small amount of calculation and simplicity, and it has high accuracy rate in evaluating multiple parameters and complex construction. This paper uses this feature to judge 


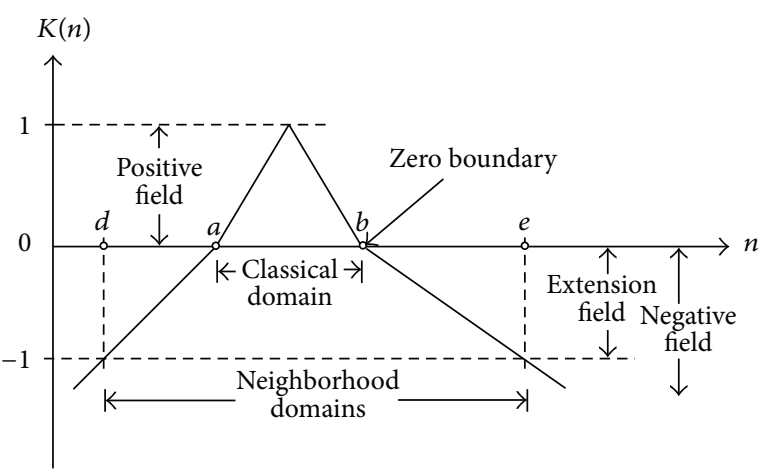

FIGURE 3: Extension set correlation function.

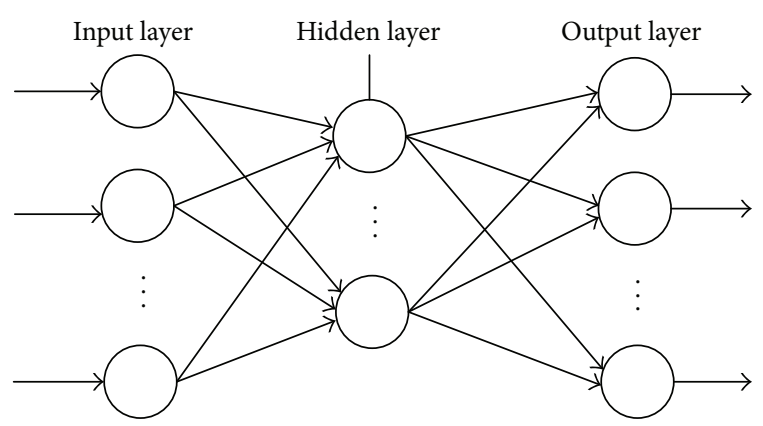

FIGURE 4: Neural network architecture.

the eigenvalue captured by Lorenz chaos synchronization system to identify the fault category of photovoltaic system.

3.2.1. Matter-Element Theory. In the extension theory, the matter-element is the basic element describing things. The general matter-element model is the mathematical model applied to extension, defined as follows [12]:

$$
R(P, C, V)=\left[\begin{array}{ccc}
P & c_{1} & v_{1} \\
& c_{2} & v_{2} \\
& \vdots & \vdots \\
& c_{n} & v_{n}
\end{array}\right]
$$

where $R$ is the matter-element, $P$ is the name of the matterelement, $C$ is the eigenvector, and $V$ is the magnitude vector corresponding to $C$.

3.2.2. Extension Set. The extension set means the range of set is extended from $-\infty$ to $\infty$ to represent the extensibility of thing characteristics, the correlation function is defined as (4), and the correlation grade of extension set can be expressed as Figure 3 [13].

Consider

$$
\begin{gathered}
K(n)=\frac{\rho\left(n, N_{o}\right)}{D\left(n, N_{o}, N_{p}\right)} \\
D\left(n, N_{o}, N_{p}\right)= \begin{cases}\rho\left(n, N_{p}\right)-\rho\left(n, N_{o}\right), & n \notin N_{o} \\
-1, & n \in N_{o}\end{cases}
\end{gathered}
$$

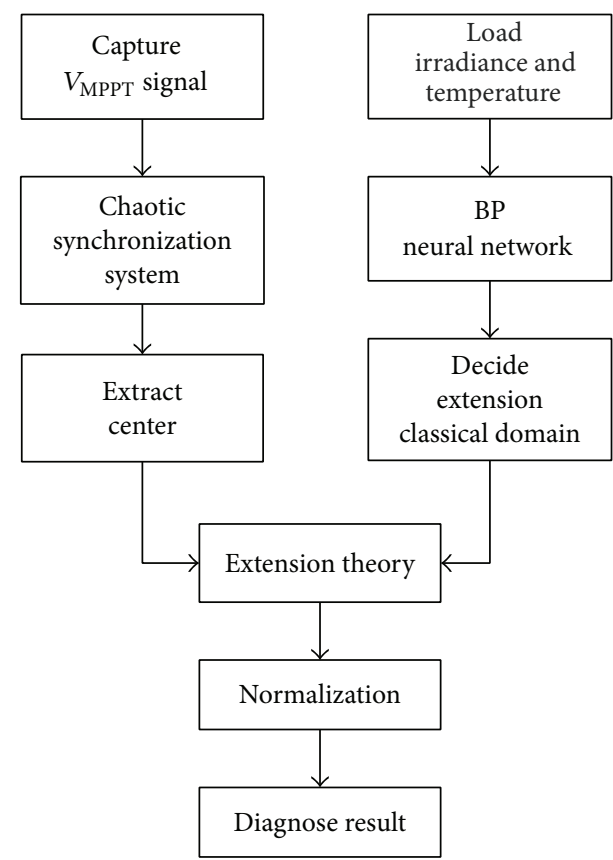

FIGURE 5: System diagnosis process of chaotic extension neural network.

$$
\begin{aligned}
& \rho\left(n \cdot N_{o}\right)=\left|n-\frac{a+b}{2}\right|-\frac{b-a}{2} \\
& \rho\left(n \cdot N_{p}\right)=\left|n-\frac{d+e}{2}\right|-\frac{e-d}{2},
\end{aligned}
$$

where $K$ is the correlation grade, $N_{o}$ is the classical domain, $N_{s}$ is the neighborhood domain, and $N_{o} \in N_{s}$.

3.3. Neural Network. The neural network is a computational theory derived from human brain structure, and it consists of many layers of neurons. The neural network is capable of calculation, memorization, reasoning, and logical decision and readjustment. The forward error backpropagation algorithm proposed by Rvomelhart and Mcclelland (1986) has excellent effect on computing nonlinear system. This paper uses this feature to calculate the eigenvalue changed at different temperatures and irradiances and uses BP neural network to determine the classical domain and neighborhood domain of extension theory.

The neural network consists of multiple layers of neurons; the input end is called input layer and the output end is called output layer. The hidden layer is between the output layer and input layer. The input layer and the output layer are the basic structures forming the neural network; the hidden layer is dispensable. The basic structure is shown in Figure 4 [14].

3.4. Chaotic Extension Neural Network Diagnosis System and Process. Figure 5 shows the system diagnosis process of chaotic extension neural network. First, the measured irradiance, temperature, and $V_{\text {MPPT }}$ are recorded, and the recorded irradiance and temperature are imported into the BP neural 


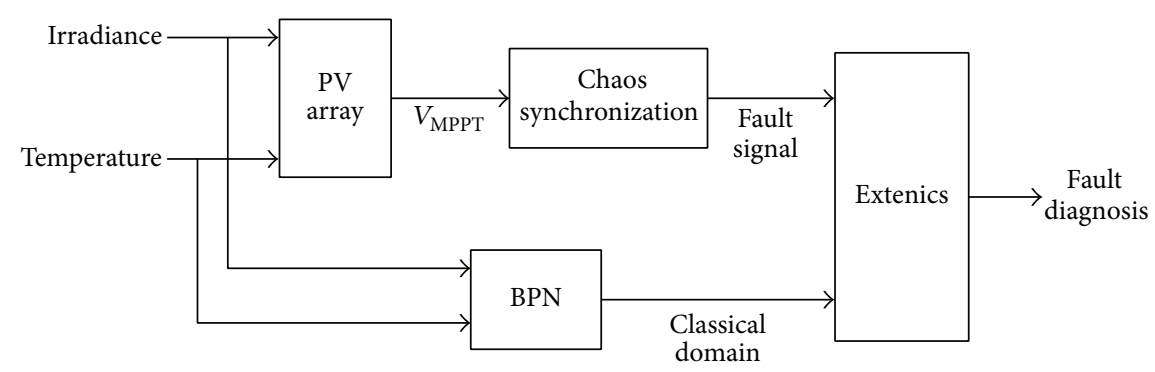

FIGURE 6: Schematic diagram of system diagnosis of chaotic extension neural network.

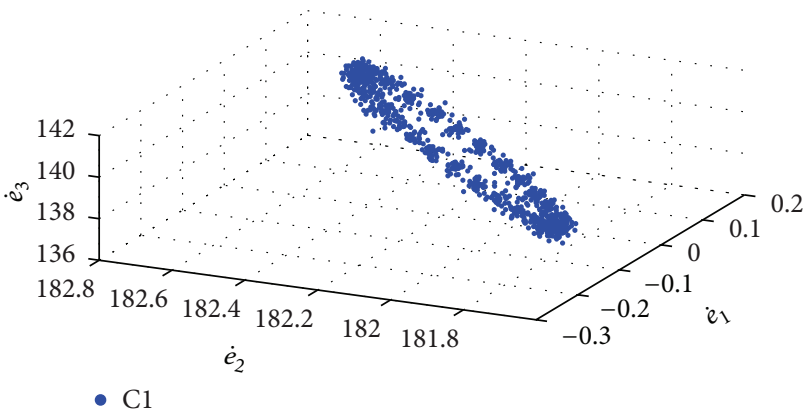

FIGURE 7: Three-dimensional diagram of normal chaotic dynamic error at $500 \mathrm{~W} / \mathrm{m}^{2} 40^{\circ} \mathrm{C}$.

network system to obtain the extension classical domain range of chaos center eigenvalue at current irradiance and temperature, and then the recorded voltage is imported into the chaos synchronization system to obtain a kinematic trajectory of chaotic dynamic system. The center point of kinematic trajectory is taken as the basis of diagnosis. Finally, the fault category of photovoltaic system can be identified as long as the obtained signal is imported into the diagnostic system of chaotic extension neural network.

\section{Simulation Results and Comparison}

This study aims to remedy the defect of unavailable diagnosis at varying irradiance and temperature in the literature [9], so the BP neural network is adopted. Figure 6 is the schematic diagram of system diagnosis.

4.1. Simulation Results. This study uses matlab 2010 and nn toolbox for simulation. The fault category is the short circuit in the solar panel of photovoltaic array, so as to simulate one normal state and eight fault states (i.e., C1 C9), as shown in Table 2.

The P-V and I-V characteristic curves are different in different states. The additional noise makes the kinematic trajectory of chaos system easier to be identified. Figure 7 is the three-dimensional diagram of chaotic dynamic error in the normal state of $500 \mathrm{~W} / \mathrm{m}^{2} 40^{\circ} \mathrm{C}$; the chaos center points in various states are taken as the range of extension classical domain, and the BP neural network is used to decide the chaos center points at different temperatures and irradiances.
TABLE 3: Sunshine intensity in different time intervals.

\begin{tabular}{lc}
\hline Time interval $(\mathrm{UTC}+08: 00)$ & Irradiance value $\left(\mathrm{W} / \mathrm{m}^{2}\right)$ \\
\hline 7:00 8:00 & $158 \sim 395$ \\
8:00 9:00 & $395 \sim 656$ \\
9:00 10:00 & $656 \sim 730$ \\
10:00 11:00 & $730 \sim 870$ \\
$11: 00 \sim 12: 00$ & $870 \sim 932$ \\
12:00 13:00 & $870 \sim 914$ \\
$13: 00 \sim 14: 00$ & $870 \sim 913$ \\
14:00 15:00 & $870 \sim 912$ \\
$15: 00 \sim 16: 00$ & $632 \sim 870$ \\
$16: 00 \sim 17: 00$ & $158 \sim 280$ \\
\hline
\end{tabular}

The sunshine intensity is about $400 \mathrm{~W} / \mathrm{m}^{2} \sim 1000 \mathrm{~W} / \mathrm{m}^{2}$ during 8:00 16:00 in Taiwan, as shown in Table 3 [15], and the temperature is about $25^{\circ} \mathrm{C} \sim 50^{\circ} \mathrm{C}$; the simulation is based on the conditions [9]. Figures 8(a), 8(b), 9(a), and 9(b) show the P-V and I-V characteristic curves at $1000 \mathrm{~W} / \mathrm{m}^{2} 25^{\circ} \mathrm{C}$ and $500 \mathrm{~W} / \mathrm{m}^{2} 40^{\circ} \mathrm{C}$.

First, the irradiance of $400 \mathrm{~W} / \mathrm{m}^{2} \sim 1000 \mathrm{~W} / \mathrm{m}^{2}$ is divided into intervals of 100 irradiance; the temperature is divided into $25^{\circ} \mathrm{C}, 30^{\circ} \mathrm{C}, 40^{\circ} \mathrm{C}$, and $50^{\circ} \mathrm{C}$ intervals as the input ends of $\mathrm{BP}$ neural network. The voltage of each interval is taken for chaos signal extraction; the obtained signal center point is used as the output end of neural network. Figures 10 and 11 show the $\dot{e}_{1}-\dot{e}_{3}$ dynamic error plane and center of different faults at $1000 \mathrm{~W} / \mathrm{m}^{2} 25^{\circ} \mathrm{C}$ and $500 \mathrm{~W} / \mathrm{m}^{2} 40^{\circ} \mathrm{C}$. The data of $\dot{e}_{3}$ center point of each interval are obtained. Table 4 shows the center point values at various irradiances and temperatures. The data are imported into the BP neural network of nn tool for training to calculate the center point of chaotic kinematic trajectory generated in different conditions. In Table 3 , the center point adds \pm 0.5 as the range of extension classical domain, and then the fault voltage signal is imported for fault diagnosis.

4.2. Comparison. The literature [9] simulated fault diagnosis at $1000 \mathrm{~W} / \mathrm{m}^{2} 25^{\circ} \mathrm{C}$, so this study used $1000 \mathrm{~W} / \mathrm{m}^{2} 25^{\circ} \mathrm{C}$, $1000 \mathrm{~W} / \mathrm{m}^{2} 30^{\circ} \mathrm{C}$, and $900 \mathrm{~W} / \mathrm{m}^{2} 25^{\circ} \mathrm{C}$ for comparison, as shown in Tables 5(a), 5(b), 6(a), 6(b), 7(a), and 7(b).

Table 8 compares the diagnostic rates and shows the diagnostic method of the literature [9]. When the irradiance is unchanged and the temperature rises by $5^{\circ} \mathrm{C}$, the diagnostic 
TABLE 4: Center point values at different irradiances and temperatures.

\begin{tabular}{|c|c|c|c|c|c|c|c|c|c|}
\hline \multirow{2}{*}{ Data } & \multicolumn{9}{|c|}{ Case } \\
\hline & $\mathrm{C} 1$ & $\mathrm{C} 2$ & C3 & $\mathrm{C} 4$ & $\mathrm{C} 5$ & C6 & C7 & $\mathrm{C} 8$ & C9 \\
\hline $\begin{array}{l}1000 \mathrm{~W} / \mathrm{m}^{2} \\
25^{\circ} \mathrm{C}\end{array}$ & 510.4643 & 466.6346 & 403.0097 & 336.9965 & 440.9046 & 367.1505 & 392.7802 & 270.0989 & 318.5866 \\
\hline $\begin{array}{l}1000 \mathrm{~W} / \mathrm{m}^{2} \\
30^{\circ} \mathrm{C}\end{array}$ & 423.9461 & 384.2504 & 331.8281 & 279.6135 & 360.4166 & 296.4365 & 319.305 & 223.3225 & 257.5316 \\
\hline $\begin{array}{l}1000 \mathrm{~W} / \mathrm{m}^{2} \\
40^{\circ} \mathrm{C}\end{array}$ & 303.6795 & 273.2271 & 238.4073 & 203.3484 & 253.9672 & 205.7853 & 224.6499 & 162.0302 & 179.1338 \\
\hline $\begin{array}{l}1000 \mathrm{~W} / \mathrm{m}^{2} \\
50^{\circ} \mathrm{C}\end{array}$ & 423.9461 & 384.2504 & 331.8281 & 279.6135 & 360.4166 & 296.4365 & 319.305 & 223.3225 & 257.5316 \\
\hline $\begin{array}{l}900 \mathrm{~W} / \mathrm{m}^{2} \\
25^{\circ} \mathrm{C}\end{array}$ & 457.1445 & 423.7284 & 371.5272 & 308.6055 & 403.0104 & 340.6735 & 362.7715 & 247.7087 & 296.5857 \\
\hline $\begin{array}{l}900 \mathrm{~W} / \mathrm{m}^{2} \\
30^{\circ} \mathrm{C}\end{array}$ & 386.6972 & 353.5165 & 306.1361 & 256.1142 & 333.0595 & 276.7268 & 297.0517 & 204.9426 & 240.1221 \\
\hline $\begin{array}{l}900 \mathrm{~W} / \mathrm{m}^{2} \\
40^{\circ} \mathrm{C}\end{array}$ & 280.6887 & 253.7645 & 218.3704 & 186.4827 & 236.5171 & 192.9238 & 209.3046 & 148.5407 & 167.4806 \\
\hline $\begin{array}{l}900 \mathrm{~W} / \mathrm{m}^{2} \\
50^{\circ} \mathrm{C}\end{array}$ & 210.7214 & 189.524 & 165.4722 & 141.7511 & 144.5628 & 141.4557 & 154.9977 & 112.7255 & 122.8688 \\
\hline $\begin{array}{l}800 \mathrm{~W} / \mathrm{m}^{2} \\
25^{\circ} \mathrm{C}\end{array}$ & 391.5921 & 370.5262 & 333.048 & 280.6498 & 356.0653 & 308.557 & 326.1221 & 223.9556 & 272.0152 \\
\hline $\begin{array}{l}800 \mathrm{~W} / \mathrm{m}^{2} \\
30^{\circ} \mathrm{C}\end{array}$ & 341.6574 & 316.5865 & 278.4199 & 231.5121 & 300.314 & 253.4934 & 270.7338 & 185.3674 & 221.2131 \\
\hline $\begin{array}{l}800 \mathrm{~W} / \mathrm{m}^{2} \\
40^{\circ} \mathrm{C}\end{array}$ & 253.9414 & 231.2014 & 200.1783 & 168.4703 & 216.3469 & 178.0942 & 192.5487 & 134.2771 & 154.3977 \\
\hline $\begin{array}{l}800 \mathrm{~W} / \mathrm{m}^{2} \\
50^{\circ} \mathrm{C}\end{array}$ & 192.0345 & 173.5387 & 150.5305 & 127.9922 & 161.1028 & 130.758 & 142.5223 & 101.6299 & 113.2707 \\
\hline $\begin{array}{l}700 \mathrm{~W} / \mathrm{m}^{2} \\
25^{\circ} \mathrm{C}\end{array}$ & 314.5517 & 304.8765 & 284.1958 & 248.2921 & 297.1806 & 267.8527 & 279.592 & 199.9536 & 241.466 \\
\hline $\begin{array}{l}700 \mathrm{~W} / \mathrm{m}^{2} \\
30^{\circ} \mathrm{C}\end{array}$ & 286.7018 & 271.0453 & 244.428 & 207.0795 & 259.892 & 225.1551 & 238.491 & 164.6638 & 199.2278 \\
\hline $\begin{array}{l}700 \mathrm{~W} / \mathrm{m}^{2} \\
40^{\circ} \mathrm{C}\end{array}$ & 222.272 & 204.5738 & 179.3767 & 149.4428 & 192.5778 & 160.7518 & 172.9791 & 119.1263 & 140.088 \\
\hline $\begin{array}{l}700 \mathrm{~W} / \mathrm{m}^{2} \\
50^{\circ} \mathrm{C}\end{array}$ & 170.4388 & 155.0974 & 134.6042 & 113.3157 & 118.4572 & 118.4572 & 128.6777 & 89.93955 & 102.556 \\
\hline $\begin{array}{l}600 \mathrm{~W} / \mathrm{m}^{2} \\
25^{\circ} \mathrm{C}\end{array}$ & 233.7565 & 230.7093 & 223.2524 & 205.8939 & 227.9525 & 215.5746 & 221.084 & 174.1138 & 201.5134 \\
\hline $\begin{array}{l}600 \mathrm{~W} / \mathrm{m}^{2} \\
30^{\circ} \mathrm{C}\end{array}$ & 222.609 & 215.5159 & 201.5031 & 177.5427 & 209.7437 & 189.2676 & 197.7411 & 144.0344 & 171.6018 \\
\hline $\begin{array}{l}600 \mathrm{~W} / \mathrm{m}^{2} \\
40^{\circ} \mathrm{C}\end{array}$ & 184.113 & 172.3014 & 154.2809 & 130.2548 & 163.7463 & 139.8199 & 149.3071 & 103.04 & 123.3908 \\
\hline $\begin{array}{l}600 \mathrm{~W} / \mathrm{m}^{2} \\
50^{\circ} \mathrm{C}\end{array}$ & 145.0369 & 133.3973 & 117.3126 & 97.81224 & 125.1117 & 104.0237 & 112.428 & 77.50333 & 90.74045 \\
\hline $\begin{array}{l}500 \mathrm{~W} / \mathrm{m}^{2} \\
25^{\circ} \mathrm{C}\end{array}$ & 159.2883 & 158.5788 & 156.8393 & 152.0567 & 157.8894 & 154.6332 & 156.2005 & 138.8777 & 150.2812 \\
\hline $\begin{array}{l}500 \mathrm{~W} / \mathrm{m}^{2} \\
30^{\circ} \mathrm{C}\end{array}$ & 156.1902 & 154.0336 & 149.3204 & 139.0552 & 152.0642 & 144.0444 & 147.6893 & 119.561 & 135.6136 \\
\hline $\begin{array}{l}500 \mathrm{~W} / \mathrm{m}^{2} \\
40^{\circ} \mathrm{C}\end{array}$ & 139.2521 & 133.2785 & 123.1959 & 107.7763 & 128.4807 & 113.8041 & 119.9614 & 86.82071 & 102.6594 \\
\hline $\begin{array}{l}500 \mathrm{~W} / \mathrm{m}^{2} \\
50^{\circ} \mathrm{C}\end{array}$ & 114.9432 & 107.4587 & 96.52619 & 81.99123 & 101.7915 & 86.67798 & 92.8941 & 64.3971 & 76.65465 \\
\hline $\begin{array}{l}400 \mathrm{~W} / \mathrm{m}^{2} \\
25^{\circ} \mathrm{C}\end{array}$ & 97.18495 & 97.04757 & 96.744 & 95.95195 & 96.91125 & 96.31457 & 96.61014 & 93.35858 & 95.54372 \\
\hline $\begin{array}{l}400 \mathrm{~W} / \mathrm{m}^{2} \\
30^{\circ} \mathrm{C}\end{array}$ & 96.67736 & 96.20672 & 95.20266 & 92.80305 & 95.74832 & 49.29442 & 49.44406 & 48.24918 & 48.96747 \\
\hline $\begin{array}{l}400 \mathrm{~W} / \mathrm{m}^{2} \\
40^{\circ} \mathrm{C}\end{array}$ & 91.52255 & 89.52814 & 85.85849 & 79.17138 & 87.73116 & 81.62739 & 84.39876 & 67.59447 & 76.26249 \\
\hline $\begin{array}{l}400 \mathrm{~W} / \mathrm{m}^{2} \\
50^{\circ} \mathrm{C}\end{array}$ & 80.47037 & 76.90738 & 71.29433 & 62.91227 & 73.94753 & 65.43214 & 69.12599 & 51.00417 & 59.25853 \\
\hline
\end{tabular}


TABLE 5: $1000 \mathrm{~W} / \mathrm{m}^{2} 25^{\circ} \mathrm{C}$ diagnostic result.

(a) Original literature

\begin{tabular}{lccccccccc}
\hline \multirow{2}{*}{ Status } & \multicolumn{1}{c}{ Case } & \multicolumn{1}{c}{ C6 } & C7 & C8 & C9 \\
\hline C1 & 1 & -0.71277 & -0.82783 & -0.98066 & -0.76204 & -0.8813 & -0.84332 & -1 & -0.94555 \\
C2 & -0.72198 & 1 & -0.77112 & -0.97482 & -0.68079 & -0.84335 & -0.79216 & -1 & -0.92876 \\
C3 & -0.97026 & -0.91917 & 1 & -0.9819 & -0.88336 & -0.88328 & -0.8429 & -1 & -0.94815 \\
C4 & -1 & -0.95903 & -0.88299 & 1 & -0.93033 & -0.8293 & -0.86864 & -0.88656 & -0.81035 \\
C5 & -0.89264 & -0.83442 & -0.85419 & -0.98472 & 1 & -0.90089 & -0.86786 & -1 & -0.95529 \\
C6 & -1 & -0.93853 & -0.82443 & -0.91072 & -0.89546 & 1 & -0.80291 & -0.93911 & -0.85451 \\
C7 & -0.98944 & -0.92881 & -0.81628 & -0.97739 & -0.88633 & -0.84873 & 1 & -1 & -0.93314 \\
C8 & -1 & -0.92787 & -0.79398 & -0.75559 & -0.87732 & -0.69945 & -0.76872 & 1 & -0.53752 \\
C9 & -1 & -0.94868 & -0.85341 & -0.8261 & -0.91271 & -0.78616 & -0.83544 & -0.78829 & 1 \\
\hline
\end{tabular}

(b) This paper

\begin{tabular}{|c|c|c|c|c|c|c|c|c|c|}
\hline \multirow{2}{*}{ Status } & \multicolumn{9}{|c|}{ Case } \\
\hline & $\mathrm{C} 1$ & $\mathrm{C} 2$ & $\mathrm{C} 3$ & $\mathrm{C} 4$ & $\mathrm{C} 5$ & $\mathrm{C} 6$ & $\mathrm{C} 7$ & $\mathrm{C} 8$ & $\mathrm{C} 9$ \\
\hline $\mathrm{C} 1$ & 1 & -1 & -0.98248 & -0.97801 & -0.98897 & -0.97954 & -0.98146 & -0.976 & -0.97732 \\
\hline $\mathrm{C} 2$ & -0.47293 & 1 & -0.62539 & -0.88383 & -0.25053 & -0.79562 & -0.68466 & -1 & -0.92394 \\
\hline $\mathrm{C} 3$ & -0.89219 & -0.62946 & 1 & -0.64614 & -0.40071 & -0.37748 & -0.0395 & -1 & -0.76833 \\
\hline $\mathrm{C} 4$ & -1 & -0.89251 & -0.60889 & 1 & -0.80349 & -0.28261 & -0.5355 & -0.61376 & -0.1127 \\
\hline C5 & -0.62227 & -0.20589 & -0.35382 & -0.79961 & 1 & -0.64747 & -0.45607 & -1 & -0.8688 \\
\hline C6 & -1 & -0.82528 & -0.36424 & -0.29859 & -0.68056 & 1 & -0.24494 & -0.81261 & -0.48768 \\
\hline C7 & -0.97836 & -0.73257 & -0.07283 & -0.59351 & -0.52725 & -0.28489 & 1 & -1 & -0.73387 \\
\hline $\mathrm{C} 8$ & -0.97527 & -0.97663 & -0.98023 & -0.99133 & -0.97776 & -0.98436 & -0.98115 & 1 & -1 \\
\hline C9 & -1 & -0.9291 & -0.74203 & -0.16318 & -0.87039 & -0.52683 & -0.69363 & -0.52549 & 1 \\
\hline
\end{tabular}

TABLE 6: $1000 \mathrm{~W} / \mathrm{m}^{2} 30^{\circ} \mathrm{C}$ diagnostic result.

(a) Original literature

\begin{tabular}{|c|c|c|c|c|c|c|c|c|c|}
\hline \multirow{2}{*}{ Status } & \multicolumn{9}{|c|}{ Case } \\
\hline & $\mathrm{C} 1$ & $\mathrm{C} 2$ & $\mathrm{C} 3$ & $\mathrm{C} 4$ & $\mathrm{C} 5$ & $\mathrm{C} 6$ & $\mathrm{C} 7$ & $\mathrm{C} 8$ & $\mathrm{C} 9$ \\
\hline $\mathrm{C} 1$ & -0.12676 & 0.535734 & 0.893778 & -0.16441 & 1 & 0.280185 & 0.713481 & -1 & -0.42615 \\
\hline $\mathrm{C} 2$ & -1 & -0.37627 & 0.781551 & 0.200473 & 0.060822 & 0.796451 & 1 & -0.88258 & -0.1439 \\
\hline $\mathrm{C} 3$ & -1 & -0.63702 & 0.036782 & 1 & -0.38265 & 0.512455 & 0.163909 & 0.131216 & 0.844341 \\
\hline $\mathrm{C} 4$ & -1 & -0.75659 & -0.30474 & 0.341188 & -0.58601 & 0.014244 & -0.21949 & 1 & 0.560711 \\
\hline C5 & -1 & -0.52001 & 0.370992 & 0.683991 & -0.18365 & 1 & 0.539099 & -0.35383 & 0.350138 \\
\hline C6 & -1 & -0.68808 & -0.10905 & 0.718689 & -0.46948 & 0.29972 & 0.000199 & 0.927234 & 1 \\
\hline $\mathrm{C} 7$ & -1 & -0.93896 & -0.82566 & -0.66369 & -0.89619 & -0.74567 & -0.80428 & -0.75234 & 1 \\
\hline $\mathrm{C} 8$ & -1 & -0.79017 & -0.40065 & 0.156169 & -0.64312 & -0.12567 & -0.32716 & 1 & 0.345408 \\
\hline C9 & -1 & -0.79017 & -0.40065 & 0.156169 & -0.64312 & -0.12567 & -0.32716 & 1 & 0.345408 \\
\hline
\end{tabular}

(b) This paper

\begin{tabular}{lccccccccc}
\hline Status & \multicolumn{1}{c}{ C1 } & C2 & C3 & C4 & C5 & C6 & C7 & C8 & C9 \\
\hline C1 & 1 & -1 & -0.98075 & -0.97562 & -0.98721 & -0.97681 & -0.97904 & -0.9731 & -0.97443 \\
C2 & -0.50963 & 1 & -0.62158 & -0.87545 & -0.30151 & -0.81663 & -0.7059 & -1 & -0.93444 \\
C3 & -0.91719 & -0.63621 & 1 & -0.63327 & -0.37768 & -0.46009 & -0.13406 & -1 & -0.80697 \\
C4 & -1 & -0.87978 & -0.58433 & 1 & -0.77377 & -0.14027 & -0.46523 & -0.61615 & -0.22971 \\
C5 & -0.67223 & -0.26196 & -0.32826 & -0.77891 & 1 & -0.6745 & -0.47794 & -1 & -0.88363 \\
C6 & -1 & -0.83391 & -0.42575 & -0.16331 & -0.68747 & 1 & -0.26122 & -0.74861 & -0.46405 \\
C7 & -1 & -0.75352 & -0.1478 & -0.51948 & -0.5362 & -0.30847 & 1 & -0.95434 & -0.72744 \\
C8 & -0.96412 & -0.96588 & -0.97019 & -0.9827 & -0.96743 & -0.97668 & -0.97193 & 1 & -1 \\
C9 & -1 & -0.93576 & -0.77789 & -0.32037 & -0.87912 & -0.54062 & -0.71426 & -0.48932 & 1 \\
\hline
\end{tabular}



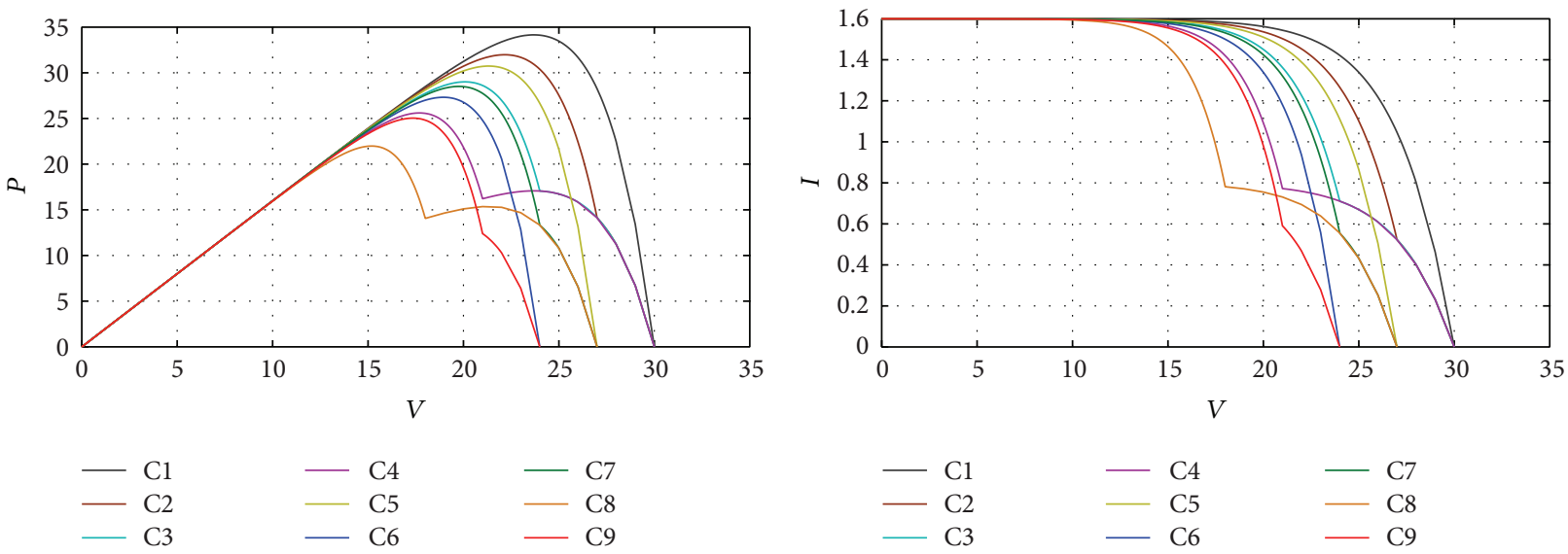

(a) P-V

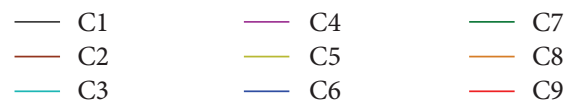

(b) I-V

FIGURE 8: P-V and I-V characteristic curves at $1000 \mathrm{~W} / \mathrm{m}^{2} 25^{\circ} \mathrm{C}$.
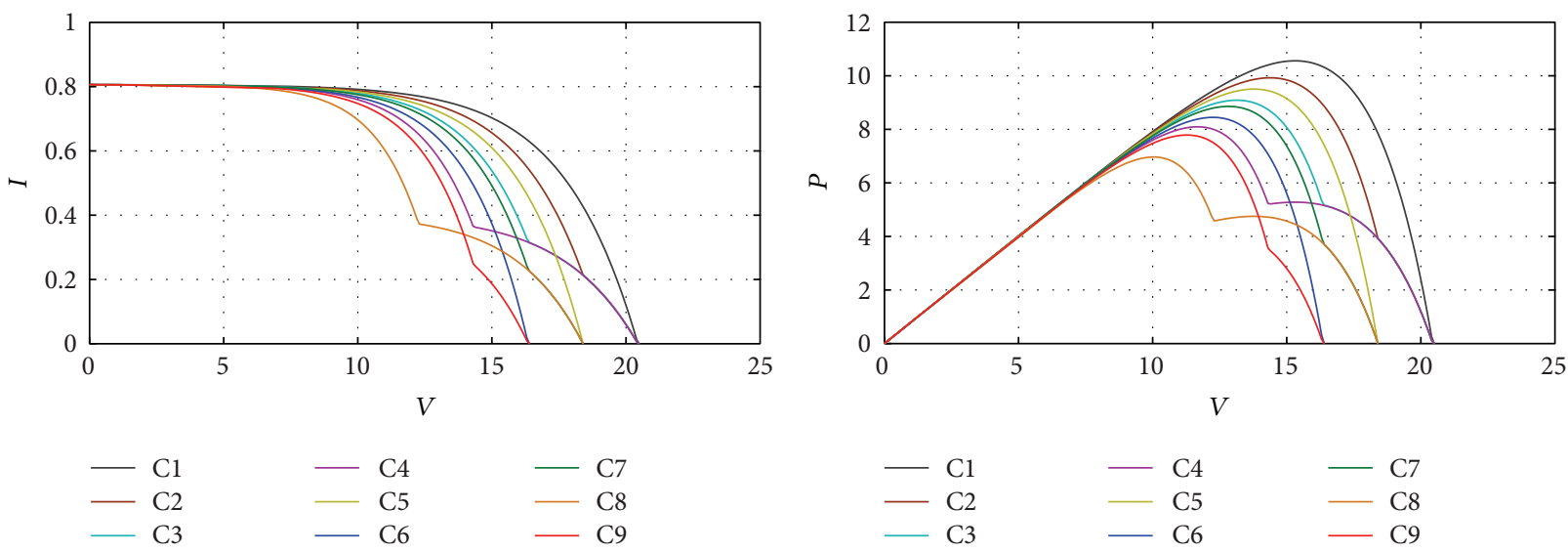

(a) I-V

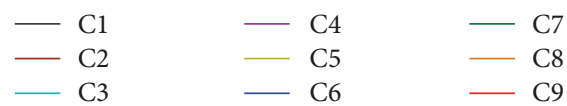

(b) P-V

FIgURE 9: P-V and I-V characteristic curves at $500 \mathrm{~W} / \mathrm{m}^{2} 40^{\circ} \mathrm{C}$.
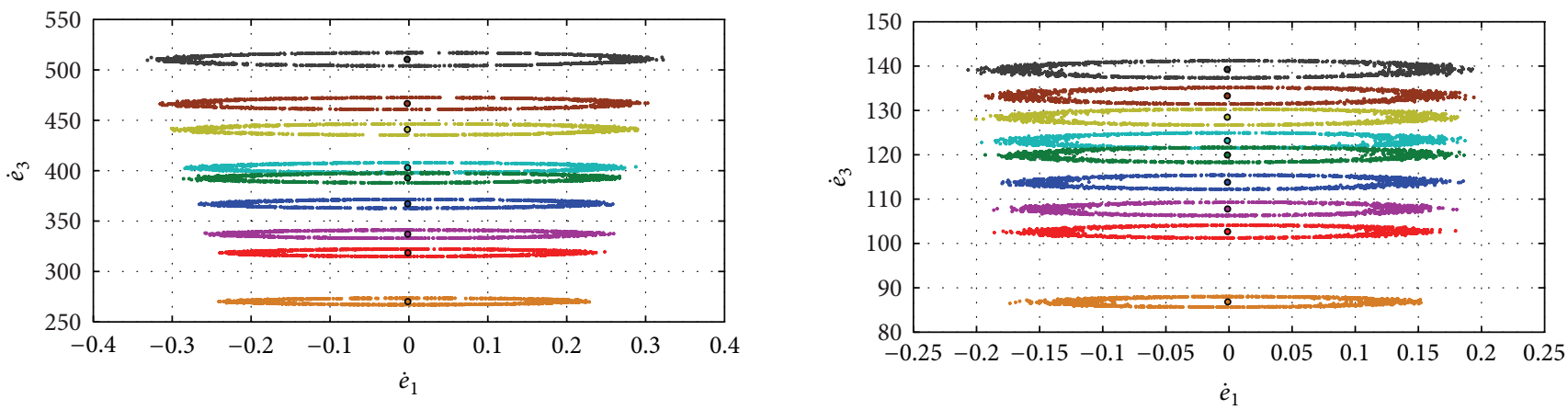

\begin{tabular}{|c|c|c|}
\hline $\mathrm{C} 1$ & & - C4 center \\
\hline $\mathrm{C} 2$ & - $\mathrm{C} 8$ & - C5 center \\
\hline $\mathrm{C} 3$ & - $\mathrm{C} 9$ & - C6 center \\
\hline $\mathrm{C} 4$ & - $\mathrm{C} 1$ center & - C7 center \\
\hline Cs & - $\mathrm{C} 2$ center & - C8 center \\
\hline C6 & - C3 center & - C9 center \\
\hline
\end{tabular}

FIGURE 10: $\dot{e}_{1}-\dot{e}_{3}$ dynamic error plane and center of different faults at $1000 \mathrm{~W} / \mathrm{m}^{2} 25^{\circ} \mathrm{C}$.

FIGURE 11: $\dot{e}_{1}-\dot{e}_{3}$ dynamic error plane and center of different faults at $500 \mathrm{~W} / \mathrm{m}^{2} 40^{\circ} \mathrm{C}$ 
TABLE 7: $900 \mathrm{~W} / \mathrm{m}^{2} 25^{\circ} \mathrm{C}$ diagnostic result.

(a) Original literature

\begin{tabular}{|c|c|c|c|c|c|c|c|c|c|}
\hline \multirow{2}{*}{ Status } & \multicolumn{9}{|c|}{ Case } \\
\hline & $\mathrm{C} 1$ & $\mathrm{C} 2$ & $\mathrm{C} 3$ & $\mathrm{C} 4$ & C5 & C6 & $\mathrm{C} 7$ & $\mathrm{C} 8$ & C9 \\
\hline $\mathrm{C} 1$ & 0.39087 & 1 & 0.35864 & -0.39016 & 0.900709 & -0.07243 & 0.23286 & -1 & -0.57939 \\
\hline $\mathrm{C} 2$ & -0.13222 & 0.533484 & 0.909789 & -0.15757 & 1 & 0.290808 & 0.727889 & -1 & -0.42149 \\
\hline $\mathrm{C} 3$ & -1 & -0.69818 & -0.1379 & -0.17831 & -0.48667 & 1 & -0.03219 & -0.76564 & -0.36617 \\
\hline $\mathrm{C} 4$ & -1 & -0.68808 & -0.10905 & 0.718689 & -0.46948 & 0.29972 & 0.000199 & 0.555377 & 1 \\
\hline C5 & -0.97245 & -0.92459 & 1 & -0.92894 & -0.89105 & -0.89051 & -0.85263 & -1 & -0.95137 \\
\hline C6 & -1 & -0.87885 & -0.65397 & 1 & -0.79396 & -0.49521 & -0.61154 & -0.695 & -0.47851 \\
\hline $\mathrm{C} 7$ & -1 & -0.76003 & -0.31456 & -0.19902 & -0.59186 & 1 & -0.23051 & -0.70642 & -0.36204 \\
\hline $\mathrm{C} 8$ & -1 & -0.79017 & -0.40065 & 0.156169 & -0.64312 & -0.12567 & -0.32716 & 1 & 0.345408 \\
\hline C9 & -1 & -0.68808 & -0.10905 & 0.718689 & -0.46948 & 0.29972 & 0.000199 & 0.921613 & 1 \\
\hline
\end{tabular}

(b) This paper

\begin{tabular}{|c|c|c|c|c|c|c|c|c|c|}
\hline \multirow{2}{*}{ Status } & \multicolumn{9}{|c|}{ Case } \\
\hline & $\mathrm{C} 1$ & $\mathrm{C} 2$ & $\mathrm{C} 3$ & $\mathrm{C} 4$ & C5 & C6 & $\mathrm{C} 7$ & $\mathrm{C} 8$ & C9 \\
\hline$\overline{\mathrm{C} 1}$ & 1 & -1 & -0.97775 & -0.97193 & -0.98589 & -0.9741 & -0.97647 & -0.96965 & -0.97134 \\
\hline $\mathrm{C} 2$ & -0.42441 & 1 & -0.60899 & -0.88998 & -0.21619 & -0.7852 & -0.67089 & -1 & -0.91837 \\
\hline C3 & -0.81912 & -0.57699 & 1 & -0.66532 & -0.35669 & -0.34659 & 0.00116 & -1 & -0.75167 \\
\hline $\mathrm{C} 4$ & -1 & -0.90157 & -0.64017 & 1 & -0.81906 & -0.34539 & -0.5728 & -0.6241 & -0.0134 \\
\hline C5 & -0.56918 & -0.16613 & -0.32758 & -0.8108 & 1 & -0.63062 & -0.43403 & -1 & -0.85962 \\
\hline C6 & -1 & -0.82945 & -0.37656 & -0.38985 & -0.68651 & 1 & -0.25984 & -0.88577 & -0.52306 \\
\hline $\mathrm{C} 7$ & -0.89864 & -0.67586 & -0.03513 & -0.61682 & -0.48165 & -0.25189 & 1 & -1 & -0.71569 \\
\hline $\mathrm{C} 8$ & -0.97645 & -0.97778 & -0.98132 & -0.99383 & -0.9789 & -0.9853 & -0.98223 & 1 & -1 \\
\hline C9 & -1 & -0.92758 & -0.73526 & -0.05418 & -0.86688 & -0.51838 & -0.6857 & -0.56027 & 1 \\
\hline
\end{tabular}

TABLE 8: Comparison of diagnostic rates.

\begin{tabular}{lcc}
\hline State & \multicolumn{2}{c}{ Category } \\
& $\begin{array}{c}\text { Diagnostic rate in } \\
\text { literature [9] }\end{array}$ & $\begin{array}{c}\text { Diagnostic rate in this } \\
\text { paper }\end{array}$ \\
\hline $1000 \mathrm{~W} / \mathrm{m}^{2}$ & $100 \%$ & $100 \%$ \\
$25^{\circ} \mathrm{C}$ & $11.11 \%$ & $100 \%$ \\
$1000 \mathrm{~W} / \mathrm{m}^{2}$ & & $100 \%$ \\
$30^{\circ} \mathrm{C}$ & $22.23 \%$ & \\
$900 \mathrm{~W} / \mathrm{m}^{2}$ & & \\
$25^{\circ} \mathrm{C}$ & & \\
\hline
\end{tabular}

rate decreases to $22.23 \%$ as the range of chaotic kinematic trajectory is changed. When the irradiance decreases to $1000 \mathrm{~W} / \mathrm{m}^{2}$ and the temperature is unchanged, the diagnostic rate is only $11.11 \%$. The diagnostic rate will decrease greatly if the temperature or irradiance changes.

\section{Conclusion}

The chaotic extension neural network diagnosis proposed in this paper is integrated with error backpropagation neural network. It can remedy the defect of large decrease in diagnostic rate when the irradiance and temperature have changed in the original literature effectively. The defect in the original literature is remedied, and the high diagnostic rate in the original literature is maintained. In comparison to the original neural network diagnosis, the addition of extension theory reduces the time of repeated training. In addition, as the chaos synchronization theory is used, when the diagnosis is difficult due to undervoltage caused by the environment, the signal can be amplified by using the advantages of chaos theory for diagnosis.

\section{Conflict of Interests}

The authors declare that there is no conflict of interests regarding the publication of this paper.

\section{References}

[1] M. Rizwan, M. Jamil, and D. P. Kothari, "Generalized neural network approach for global solar energy estimation in india," IEEE Transactions on Sustainable Energy, vol. 3, no. 3, pp. 576584, 2012.

[2] H. A. Talebi and K. Khorasani, "A neural network-based multiplicative actuator fault detection and isolation of nonlinear systems," IEEE Transactions on Control Systems Technology, vol. 21, no. 3, pp. 842-851, 2013.

[3] S. Yousef and A. K. Mahmood, "Fault diagnosis in internal combustion engines using extension neural network," IEEE Transactions on Industrial Electronics, vol. 61, no. 3, pp. 14341443, 2014.

[4] Y. Wu, Q. Lan, and Y. Sun, "Application of BP neural network fault diagnosis in solar photovoltaic system," in Proceedings of the IEEE International Conference on Mechatronics and Automation (ICMA '09), pp. 2581-2585, Changchun, China, August 2009. 
[5] S. Syafaruddin, E. Karatepe, and T. Hiyama, "Controlling of artificial neural network for fault diagnosis of photovoltaic array," in Proceedings of the 16th International Conference on Intelligent System Applications to Power Systems (ISAP '11), Hersonissos, Greece, September 2011.

[6] T. Shimakage, K. Nishioka, H. Yamane, M. Nagura, and M. Kudo, "Development of fault detection system in PV system," in Proceedings of the IEEE 33rd International Telecommunications Energy Conference (INTELEC '11), pp. 1-5, Amsterdam, The Netherlands, October 2011.

[7] Y. Zhao, L. Yang, B. Lehman, J.-F. de Palma, J. Mosesian, and R. Lyons, "Decision tree-based fault detection and classification in solar photovoltaic arrays," in Proceedings of the 27th Annual IEEE Applied Power Electronics Conference and Exposition (APEC '12), pp. 93-99, Orlando, Fla, USA, February 2012.

[8] M. Tadj, K. Benmouiza, A. Cheknane, and S. Silvestre, "Improving the performance of PV systems by faults detection using GISTEL approach," Energy Conversion and Management, vol. 80, pp. 298-304, 2014.

[9] C.-T. Hsieh, H.-T. Yau, and J. Shiu, "Chaos synchronization based novel real-time intelligent fault diagnosis for photovoltaic systems," International Journal of Photoenergy, vol. 2014, Article ID 759819, 9 pages, 2014.

[10] C.-H. Huang, C.-H. Lin, and C.-L. Kuo, "Chaos synchronization-based detector for power-quality disturbances classification in a power system," IEEE Transactions on Power Delivery, vol. 26, no. 2, pp. 944-953, 2011.

[11] K.-H. Chao, S.-H. Ho, and M.-H. Wang, "Modeling and fault diagnosis of a photovoltaic system," Electric Power Systems Research, vol. 78, no. 1, pp. 97-105, 2008.

[12] M. H. Wang and H. H. Tsai, "Fuel cell fault forecasting system using grey andextension theories," IET Renewable Power Generation, vol. 6, no. 6, pp. 373-380, 2012.

[13] K.-H. Chaoa, S.-H. Hob, and M.-H. Wang, "Application of extension theory to vibration fault diagnosis of generator sets," Electric Power Systems Research, vol. 78, no. 1, pp. 97-105, 2008.

[14] L. Boukezzi and A. Boubakeur, "Prediction of mechanical properties of XLPE cable insulation under thermal aging: neural network approach," IEEE Transactions on Dielectrics and Electrical Insulation, vol. 20, no. 6, pp. 2125-2134, 2013.

[15] C. Y. Chang, C. J. Li, and C. W. Cheng, "Application of hybrid solar light collectors and artificial light sources on interior lighting," Journal of Design, vol. 16, no. 2, pp. 45-60, 2011. 


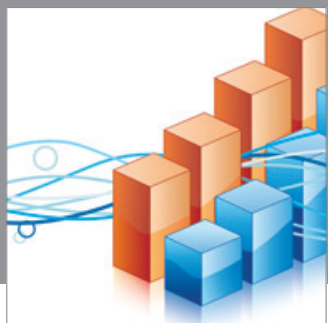

Advances in

Operations Research

mansans

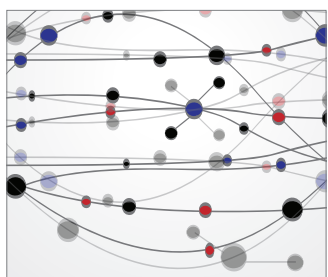

The Scientific World Journal
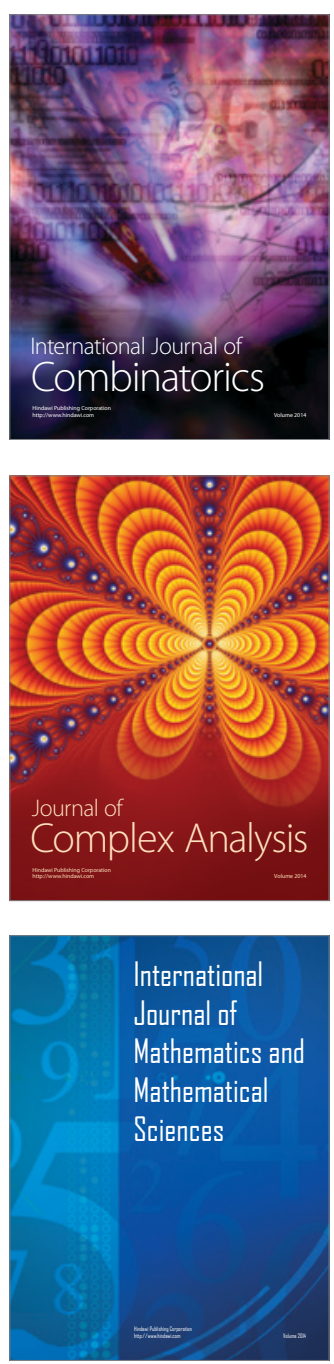
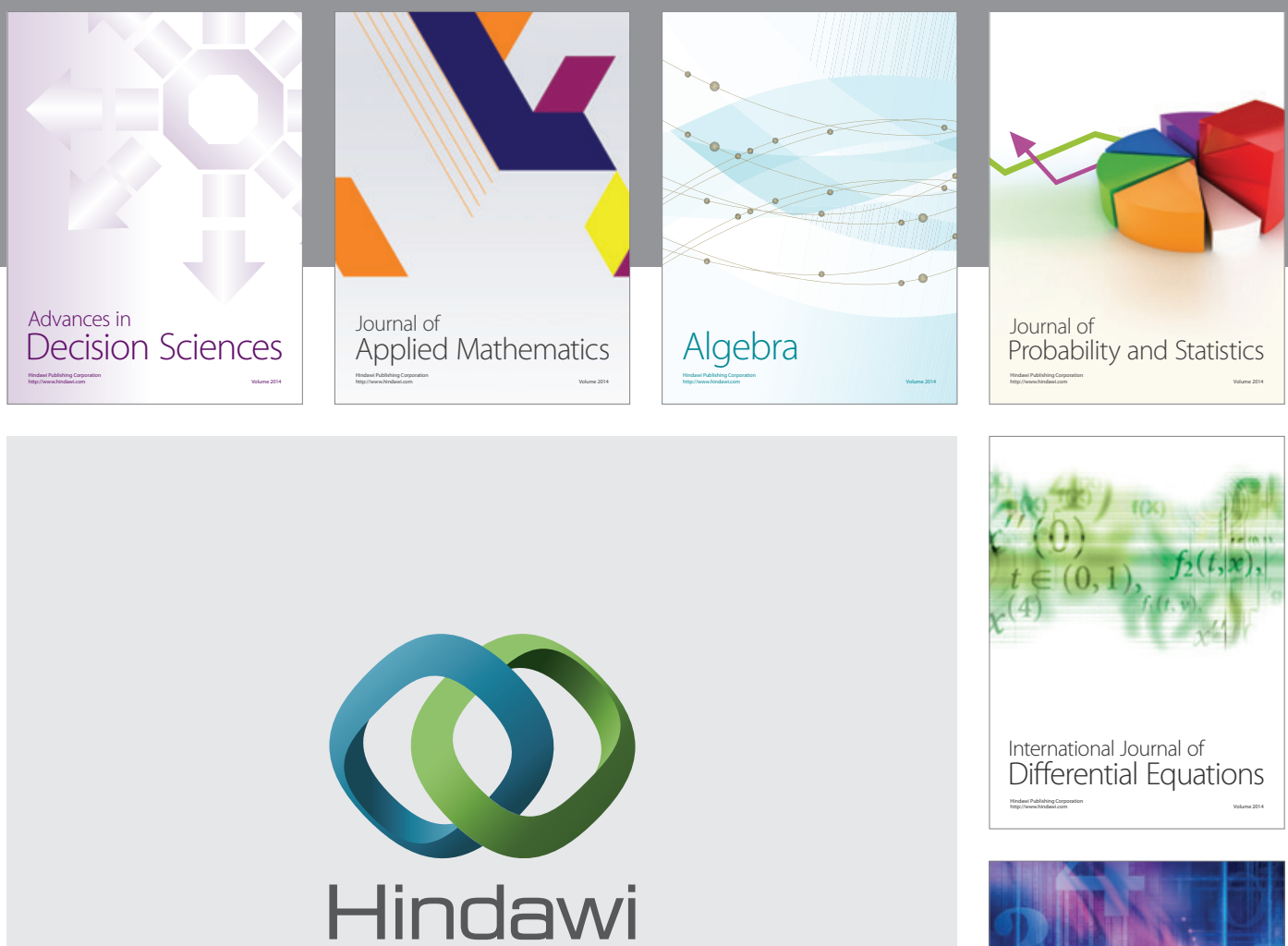

Submit your manuscripts at http://www.hindawi.com
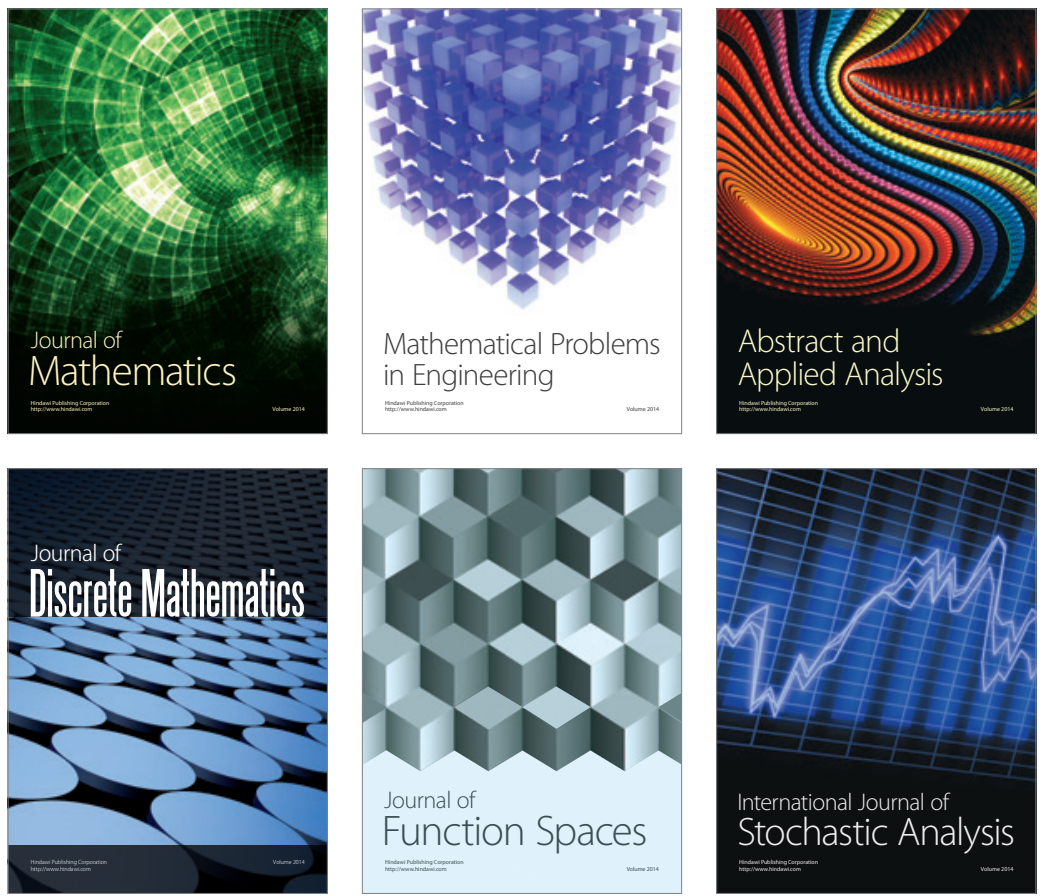

Journal of

Function Spaces

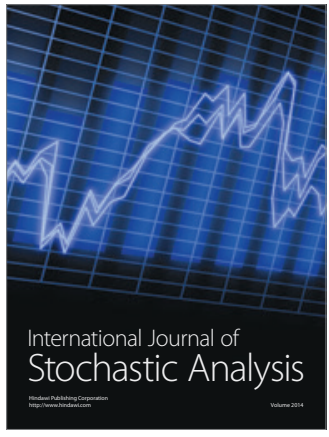

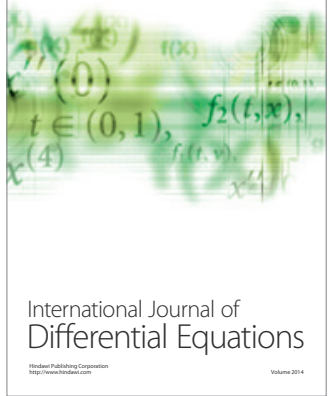
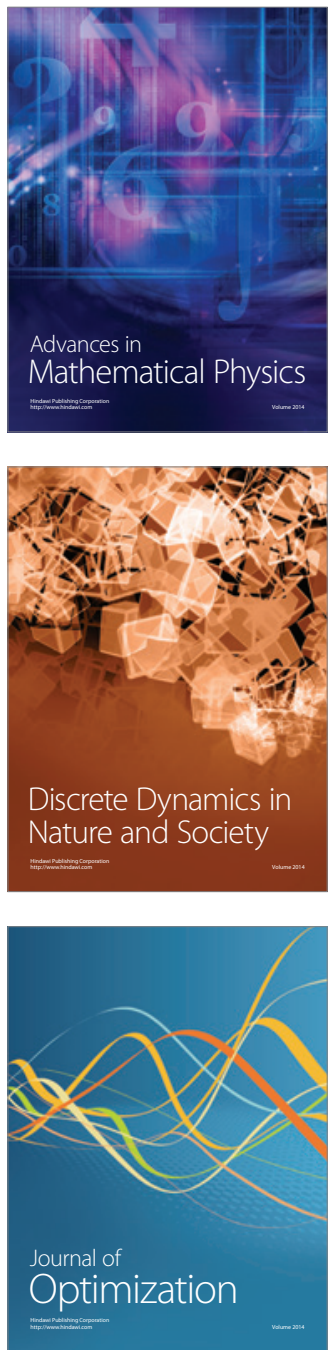